\title{
Can Institutional Investors Fix the Corporate Governance Problem? Some Danish Evidence
}

\author{
Rose, Caspar
}

Document Version

Final published version

Publication date:

2005

License

CC BY-NC-ND

Citation for published version (APA):

Rose, C. (2005). Can Institutional Investors Fix the Corporate Governance Problem? Some Danish Evidence.

Link to publication in CBS Research Portal

\begin{abstract}
General rights
Copyright and moral rights for the publications made accessible in the public portal are retained by the authors and/or other copyright owners and it is a condition of accessing publications that users recognise and abide by the legal requirements associated with these rights.

\section{Take down policy}

If you believe that this document breaches copyright please contact us (research.lib@cbs.dk) providing details, and we will remove access to the work immediately and investigate your claim.
\end{abstract}




\title{
Can Institutional Investors Fix the Corporate Governance
}

\section{Problem? Some Danish Evidence}

\author{
CKK Working Paper by Caspar Rose*
}

Version of April 8, 2005

\begin{abstract}
It has been advocated within corporate governance that institutional investors may discipline management in listed firms and thereby alleviate the free rider problem associated with dispersed ownership. This article tests this hypothesis using a sample of Danish listed firms during 1998-2001 seeking to determine, whether ownership by institutional investors impacts performance, measured by Tobin's q. Using three stage least squares, it is shown that aggregate ownership by institutional investors does not influence firm performance. However, when decomposing the results, it is found that joint ownership by the largest two Danish institutional investors, has a significant negative impact on firm performance. Ownership by banks, and to a lesser, extent insurance companies significantly influences firm performance positively. The results somehow challenge the conventional wisdom, arguing that the black box view of institutional investors should be abandoned. Therefore, it is suggested that a more careful analysis should be devoted to each institutional investor's own legal environment.
\end{abstract}

JEL Classification: L25, G2 and G3

Keywords: Corporate governance, institutional investors, concentrated ownership, agency costs

\footnotetext{
* Associate professor, Copenhagen Business School, Centre for Financial Law, Solbjergvej 3. 1. sal. DK- 2000 Frederiksberg. E-mail cr.ckk@ cbs.dk Phone +45 38152851 and Fax +45 381526 60. I am grateful to Anders Larsen for excellent research assistance as well as to Hans Kurt Kvist for useful comments. The paper also benefited from presentation at the Annual workshop in Corporate Governance, April 8, 2005 at the Copenhagen Business School.
} 


\section{Introduction}

The increase of institutional funds in the industrialized countries has been tremendously rapid within the last thirty years, where institutional investors are the largest group of owners managing an enormous amount of capital. As a result, institutional investors, are as a group, considered the most influential actors on the scenes of the capital markets. In the debate on corporate governance and in particular, the role of institutional investors, more pressure has been put on institutional investors to be more active in their ownership, e.g. to exercise their proxies and their voting rights at the firms' general meetings. Furthermore, it has been advocated that institutional investors may facilitate the promise of "relationship investing" (see e.g. Blair (1995)), which describes a situation where they are engaged in overseeing management in the long term instead of being detached or passive.

Due to the separation of ownership and control, agency costs exist, as investors are not able to monitor management without incurring costs. This is foreseen by the external providers of capital, so even if management has identified projects with positive net present value, it may find it difficult to convince capital suppliers to invest their wealth in the firm. A statement where management promises not to exploit the firm's resources is in the terminology of game theory, simply not credible. Moreover, when institutional investors hold a substantial proportion of shares, this might discipline management, since the free rider problem associated with dispersed ownership would be alleviated. Contrary to small investors, institutional investors are more able to absorb the costs from monitoring management and engaging in active ownership.

One the other hand, one may argue that if all small investors believe that institutional investors will undertake the monitoring role, the free rider problem may be enhanced. The reason is that this would destroy the incentives for small investors to play any active role at all. 
Proponents of institutional activism argue that strengthening institutional investors' ownership would benefit society as a whole, because they would be able to influence managerial actions, so that the interests of the society and the company more coincides, see e.g. Black (1992), as well as Monks and Minow (1995) for this view.

At first glance, this may appear as a satisfactory solution. However, this neglects the fact that there are other remedies to mitigate externalities imposed by a firm on its surroundings, which might turn out more adequate. Recall the famous Coase theorem, which states that given the absence of transaction costs, parties will negotiate and reach an efficient bargaining solution. Property rights will be assigned to the party, who is most willing to pay for a specific right, e.g. a right to pollute the firm's surroundings or abstain from such an activity. Instead of letting institutional investors influence managerial decisions, it might prove more efficient to remove impediments, so that management may bargain with the firm's stakeholders, see e.g. Rose (2004) who argues for a narrow duty of loyalty for management, emphasizing the contractual approach between management and the firm's stakeholders. Institutional investors cover a wide group of heterogeneous investors, which are all subjected to different legislations. They include pension funds, banks, insurance companies, mutual funds, mutual companies and investment funds/foundations. Some of the largest institutional investors have all been very active in exercising their rights as owners, e.g. CalPERS, the New York City pension fund, TIAA-CREF. They have sought e.g. to challenge excessive executive compensation, the adoption of takeover defences, to split the roles of chairman and CEO and to ensure enough independent directors. However, generally, institutional activism has been limited. The reason is that regulation often puts various restrictions on the ownership by institutional investors, such as, requiring them not to have a dominant stock holding in a firm.

In Denmark, the largest two institutional investors (ATP and LD) have been very active in the debate on corporate governance pointing out, what they regard, as weaknesses embedded in the Danish 
corporate governance system. For instance, both investors have criticised the use of shares with dual class voting rights, which are very common in Denmark, as well as been reluctant towards foundation ownership, emphasizing the lack of transparency associated with foundation ownership.

Denmark got its own guidelines or code of corporate governance in December 2001, based on a report made by the so-called Nørby committee, which was revised in December 2003 (the director of ATP, Lars Rohde is a member of the committee). Thus, the Copenhagen Stock Exchange requires all listed firms to follow the recommendations or to explain if a company does not comply with the recommendations. Contrary to e.g. the Combined Code, the Danish Nørby report does not contain any recommendations concerning the role of institutional investors. The Combined Code states that companies should be ready, where practicable, to enter into a dialogue with institutional investors based on the mutual understanding of objectives. Thus, the Combined Code mentions that institutional shareholders should have a responsibility to make considered use of their votes. As more attention is drawn to the role of institutional investors, this naturally spurs the need to understand the economic consequences of institutional ownership.

This article finds that institutional investors are not able to solve the corporate governance problem. Specifically, using a sample of Danish listed firms during 1998-2001 and applying 3SLS, it is found that aggregate ownership by institutional investors on overall, does not impact performance measured by Tobin's q. Using piecewise regression, it is shown that ownership by institutional investors between zero and 10 percent, significantly influences firm performance negatively. On the other hand, ownership between 10 and 33 percent, as well as over 33 percent, does not impact performance significantly. However, decomposing the results reveals that the joint ownership by the two largest Danish institutional investors has a significant, negative impact on firm performance. On the other hand, the analysis shows that ownership by banks and to a lesser extent insurance companies has a positive, significant impact on firm performance. 
The results, somehow, challenge the conventional wisdom, arguing that the black box view of institutional investors should be abandoned. It is suggested that a more careful analysis should be devoted to the assessment of the legal impediments for institutional activism. It is also argued that more attention should be drawn to the design of incentive schemes for fund managers employed by institutional investors, in order to mitigate agency costs within the organization of institutional investors.

The article is organized as follows. In the next section, I motivate the hypothesis followed by a literature review in section 3. The data is described in section 4, and section 5 outlines the methodology. Results are shown in section 6 followed by a discussion in section 7 . The article ends with a short conclusion in section 8 .

\section{Hypothesis}

As mentioned, institutional investors may reduce the free rider problem caused by dispersed ownership and therefore avoid managerial focus on short-termism. For instance, small investors may find it more difficult to form coalitions, or to enforce their rights in courts. The article tests the following hypothesis empirically.

Firm performance increases when institutional investors increase their ownership

Furthermore, one may hypothesize that institutional investors could influence management, not only to take the interests of shareholders into account, but also to serve the interests of other stakeholders. To illustrate, consider e.g. a pension fund, where all the members have strong preferences against firms that directly or indirectly use child labor. Even if such firms may earn a higher profit due to lower costs, it might be reasonable for a pension fund not to invest in such firms, due to the members' strong 
preferences against the use of child labor. Another question is, if it is optimal from the perspective of society, i.e. if no children were allowed to work, and as a result instead died of starvation. In other words, institutional investors may consider a broader view, trying to get management not only to care about the shareholders' interests, which to some extent can be justified, since shareholders are usually considered residual claimants, see e.g. Fama and French (1983).

On the other hand, one could argue that enhanced ownership by institutional investors does not necessarily influence performance positively. Specifically, it is doubtful that institutional investors act, as if they have a long investment horizon. The reason is that a portfolio manager employed by institutional investors is evaluated yearly, by comparing each portfolio manager's performance, with a selected peer group or benchmark. As a consequence, the portfolio manager might care less about the return from their investments in the future thirty years from now when the pension costumer intends to enjoy the capital accumulation Put differently, there is an embedded agency problem within institutional investors.

Furthermore, it is also questionable whether institutional investors would always act in a way that benefits all investor groups. Naturally, managements in listed firms need to care about the preferences of the large shareholders, since they are the owners and could replace incumbent management at the forthcoming general meeting. If institutional investors hold a high stake in a company, there is an inherent risk that institutional investors might seek to derive private benefits on behalf on all the other minority shareholders. For instance, institutional investors might get inside information, when management holds investor meetings or is in contact with the dominant owners. Even though, this is prohibited by law, it is still quite difficult to prove afterwards by the authorities. Collusion between large block holders and management may be sanctioned by the law, since this could violate the principle of the equal treatment of shareholders that prevails in the legislation of most countries, including Danish company law. 
The legal protection of (minority) shareholders plays a key role in corporate governance, see e.g. La Porta et al. (1997), who find that countries with poorer investor protection, including protection of minority shareholders, have smaller and narrower capital markets.

The opinion that institutional investors acting as active owners could discipline management may also be ambiguous, as institutional investors often are impeded by legal restrictions, and consequently they do not qualify as active owners. For instance, in some countries, such as the US, banks and insurance companies are not allowed to hold large portions of equity in non-financial firms, see Blair (1995) for a review of US institutional investors. This is contrary to Germany, where banks play a major role, not only as owners, because the German legislation prescribes that, if a shareholder does not actively require the right to vote for himself, the voting right is automatically transferred to the bank. German bank directors are also allowed to seat on the supervisory board (Aufsichtsrat) in non-financial firms. Contrary to the Danish system, the German institutional framework, therefore, especially supports the influence on banks.

In addition, the presence of large institutional owners might even enhance the free rider problem, since smaller investors would rely on institutional investors to monitor and control management, so they would not spend resources doing these activities themselves. Monitoring and controlling management is costly, so in order to save these costs, institutional investors may facilitate an index tracking strategy. This involves a passive investment strategy, and if capital markets are efficient, stock picking would be wasteful. Thus, if institutional investors hold efficient portfolios, they have eliminated the firm specific risk by diversification and very rarely have a motive to act as active owners. 


\section{Literature}

Several theoretical papers explore how ownership influences managerial incentives. Grossman and Hart (1980) derive a formal model, where they show that small investors do not have a big enough stake in the firm to absorb the costs of watching the management.

Shleifer and Vishny (1987) formulate a model where they show that when a large shareholder increases his holdings, a takeover becomes more likely and as a result, the firm's share price increases. Moreover, when a takeover does occur, the premium is lower, because when a large shareholder owns more, he is willing to take over for a smaller increase in the firm's profit. Bids do not only signal a smaller increase in average post takeover profits, but bids also become more likely and are more heavily reflected in the pre takeover market price. Shleifer and Vishny (1987) further show that an increase in the legal and administrative costs of takeovers, reduces the welfare of small investors, despite an increase in the takeover premium.

Admati, Pfleiderer and Zechner (1994) study large shareholder activism and risk sharing in financial markets. Their model relies on a traditional asset pricing model with a number of risky securities as well as a risk free asset. They assume that investors are risk averse, but their model only assumes that there is one single large investor. Moreover, they show that in a portfolio context large shareholder activism is consistent with equilibrium, even if the initial holdings of the large shareholder are zero. Maug (1998) analyzes how market liquidity influences the free rider problem. He develops a model, where he shows that a more liquid market leads to more monitoring, because it allows an investor to cover monitoring costs through informed trading. If stock markets are less liquid, large shareholders will engage in less monitoring. In order to avoid the commitment to monitor, the large shareholder will have smaller stakes in more companies by diversification.

Kahn and Winton (1998) analyze how speculation influences institutional intervention. The y argue that intervention increases the value of the institution's existing shares, but they show that intervention 
only increases the institution's trading profit, if it enhances the precision of the institution's information, compared to the uninformed investors. They show that when costs of intervention fall, more informed traders enter the market, making prices more informative, diminishing the institution's trading profits, and thus reducing the importance of trading profits in the institutions intervention decision. Also, as intervention becomes more likely to succeed, or the impact of successful intervention increases, the trading impact increases in importance.

One of their policy implications is that concentration levels should be higher in relatively transparent well- understood firms $\alpha$ industries, than in firms or industries that are less transparent, i.e. where information is harder to obtain.

Hartzell and Starks (2003) argue that institutional investors serve a monitoring role in mitigating the agency problem between managers and shareholders. Specifically, they find that institutional ownership is positively related to the pay for performance sensitivity of executive compensation, and negatively related to the level of compensations. The result is robust when they control for firm size, industry and investment opportunities.

Burkart, Gromb and Panunzi (1997) challenge the notion that the reduction of managerial discretion by large outside investors is purely beneficial. They construct a model, where they show that outside ownership comes with costs and benefits. Specifically, they show that even though, tight control by outside shareholders may be ex post efficient, it also constitutes an ex ante expropriation threat that reduces the level of non-contractible investment by managers. The underlying reason is that a dispersed ownership structure commits shareholders not to exercise excessive control. One of the consequences of their model is that monitoring can reduce the effectiveness of incentive schemes based on performance.

Duggal, R. and J. Millar (1999) empirically challenge the ability of institutional investors to monitor management. Based on takeover decisions during 1985-1990, they examine the impact of institutional 
ownership and performance, but they do not find evidence that active institutional investors, as a group, enhance efficiency in the market for corporate control. Duggal and Millar also identify a number of institutional investors that have a reputation for exercising an active ownership, but regressing bidder returns against active institutional investors only result in an insignificant relationship.

On the other hand, Wahal and McConnell (2000) find no support for the contention that institutional investors cause managers to behave myopically. Based on a large sample from 1988-1994 of US firms, they document a positive relation between industry adjusted capital expenditures, as well as research and development, and the proportion of shares held by institutional investors. Both are proxies for management's degree of long-term orientation.

Prevost and Rao (2000) study whether institutional investor activism benefits shareholders, using an event study of shareholder proposals surrounding proxy mailing dates. Contrary to earlier studies, they find a strong negative wealth effect surrounding the proxy mailing dates of firms targeted by two very visible, publicity-seeking types of sponsors: CalPERS and coalitions of public funds sponsoring or cosponsoring one or more proposals on the same proxy. Prevost and Rao argue that the results are consistent with the hypothesis that a formal proposal submission signals a breakdown in the negotiation process between the funds and management.

Louis, Chan and Lakonishok (1993) examine the price effect of institutional stock trading and they find that the average effect is small. They also document market asymmetry between price impact of buys versus sells, which is related to various hypotheses on the elasticity of demand for stocks, the costs of executing transactions and the determinants of market impact. For instance, they argue that institutional purchase might be a stronger signal of favourable information, whereas there are many liquidity motivated reasons to dispose a stock, see also Sias and Starks (1997) for an analysis of return autocorrelation and institutional investors. 
Bhagat, Black and Blair (2004) conduct a large study of ownership and performance over a thirteen year period focusing on, whether relationship investing has a positive impact on firm performance. They document a significant secular increase in large block shareholding with a sharp percentage increase in these holdings by mutual funds, partnerships, investment advisors and employee pension plans. However, most institutional investors, when they purchase large blocks, sell the blocks relatively quickly afterwards. Bhagat, Black and Blair provide a mixed result of whether relational investing affects firm performance. In the late 1980s, where there was a high takeover wave, there was a significant relation between relational investing and firm performance, but this pattern was not found in the other periods. In essence, they do not find any persistent and sustainable effect of relational investing on firm performance. Thus, they argue that the idea of relational investing must be more carefully specified in theory.

Ackert and Athanassakos (2001) focus on agency considerations among institutional investors. They show that market frictions are important concerns for institutional investors, when they make portfolio allocation decisions. The availability of information about a firm is a significant friction, so that institutional holding increases with market value and the firm's visibility, as proxied by the number of analysts following the firm. They also show that institutions adjust their portfolios away from highly visible firms at the beginning of the year, but increase their holdings in these firms as the year-end approaches, which is, as they argue, consistent with the gamesmanship hypothesis.

In contrast to several other studies that focus on firm level effects of institutional ownership, Davis (2002) examines how institutional share holding in the largest countries on aggregate affect macro economies. Specifically, Davis links the development of institutional investors to important indicators of corporate sector performance, such as increasing dividend distribution, less fixed investment and higher productivity growth. Life insures and Pension funds are most influential. 
Neumann and Voetmann (2003) carry out an event study measuring the impact on share prices from strategic and institutional investors at the Copenhagen Stock Exchange. They find that changes in ownership matter. Moreover, they find that when large institutional and strategic investor's ownership is high i.e. beyond 20 percent, the security performance decreases, whereas between 5 and 20 percent threshold security performance remains constant. Only when changes in ownership are between zero and 5 percent, security performance increases. The authors attribute this relation to increasing entrenchment benefits when ownership passes the high threshold.

\section{Data}

The data consist of a unique sample of all Danish firms listed at the Copenhagen Stock Exchange during 1998-2001. Banks and insurance companies are excluded, as well as a few number of football clubs due to the difficulty calculating Tobin's q for these firms (there are special accounting rules for these sectors). In addition, six companies fom the sample are also excluded due to lack of relevant data, including the large Shipping companies D/S Svendborg and D/S 1912 (now merged as the APM Group). The latter is a consequence of the non-transparent ownership structure of these two firms during the considered period.

The primary source of data consists of the firms' annual accounts, i.e. the financial data is obtained by manually collecting each firm's annual accounts for each year. Stock market information is obtained from The Copenhagen Stock Exchange (www.cse.dk). Stock market data is corrected for new stock issues and splits. All financial ratios are calculated in accordance with the recommendations made by the Danish Association of Financial Analysts (DAF).

A small proportion of firms do not report the exact amount of blockholders (owning more than 5 percent), so the actual number of blockholders may be underestimated in the data. Furthermore, if a company holds shares of its own, this amount is excluded from the data, since a company is not 
entitled to vote on their own shares according to Danish Law. Thus, if an investor holds shares through a company he controls, this is included as his/her holding regardless of the company's legal entity. This gives a sample of 443 firm-time observations. However, 9 firms had Tobin's q that exceeds 5 (typically newly listed technology stocks), so these (outliers) firms have been excluded from the analysis reducing the sample size to 434 firms. Based on the data, the article constructs the following variables.

\section{LIST OF VARIABLES}

The abbreviations in the parentheses are labels used in the correlation matrix.

- TOBIN'Q (q): The market value of equity plus book value of debt all divided with book value of assets

- INSTI: Cumulative ownership of all institutional investors without foreign investors

- INSUR: Ownership by insurance companies

- BANK:Ownership by banks

- INVEST: Ownership by mutual funds

- PENS: Ownership by pension funds

- LDATP: Ownership by ATP (Arbejdsmarkedets Tillægspension) and LD (Lønmodtagernes Dyrtidsfond)

- FOREIGN:Foreign ownership

- TRUSTS: Ownership by trusts or foundations

- DUALCL: Dummy variable equal to 1, if firms have shares with dual class voting rights

- $\quad$ SIZE (SIZE): Net turnover for the group 
- OPTIONS (OPT): Dummy variable equals one if the firm has granted management incentive contracts, otherwise it equals zero

- LnCAPEXP: The natual log of net capital expenses

- TRADE/SERVICE (TS): Dummy variable equals one, if a firm belongs to the trade and service industry, otherwise it equals zero

- MANUFACTORING (MAF): Dummy variable if a firm belongs to the manufacturing industry, otherwise it equals zero

- SHIPPING (SHIP): Dummy variable equals one, if a firm belongs to the shipping industry, otherwise it equals zero

\section{Methodology}

This paper conducts a cross-sectional regression analysis, where all the firm's observations during the period are staged. Tobin's q is used to measure firm performance, which is a measure of the firm's ability to generate profits above the replacement value of the existing assets in the firm. A high value of $\mathrm{q}$ is usually a strong indication for valuable growth opportunities, due to a strong competitive advantage. Despite the drawbacks of Tobin's q, it is often applied in corporate governance. In particular, it is dubious whether the de-nominator in the q ratio, is an adequate proxy for the firm's replacement costs.

The proportion of ownership by institutional investors serves as the key explanatory variable and the following control variables are also included: Presence of incentive contracts, firm size, industry dummies as well as year dummies.

When performing simple OLS, one assumes that firm performance is the only endogenous variable, i.e. ownership by institutional investors influences firm performance. However, as recognized in the corporate governance literature, the causation may go in the opposite direction, i.e. firm performance 
may impact ownership by institutional investors. As a consequence, both Tobin's q and institutional ownership may be regarded as endogenous variables. Technically speaking, OLS assumes the regressors are uncorrelated with the residual, but when current endogenous variables appear as regressors in other equations, this assumption is violated and OLS parameter estimates are biased.

To remedy this problem, one may construct a simultaneous equation system where the equations are estimated using instrumental variables. Instruments are by definition unrelated to the endogenous variables, and any variables that are thought to be exogenous and independent of the disturbance are able to serve as instruments. However, as is argued by Himmelberg, Hubbard and Palia (1999), insufficient instruments make it difficult to establish a robust relation between ownership and performance.

The article uses four instruments, namely OPTIONS and lnCAPEXP serving as instruments for Tobin's q. There is reason to believe that when management receives incentive contracts, this will help to alleviate agency costs thereby impacting firm performance positively. At the same time, it seems unlikely that institutional investors may influence the decision to offer incentive contracts to 'the management. The second instrument is the natural log of net capital expenditures. It is reasonable to expect that when a firm pays a higher amount of capital expenditures, this may reflect that the firm has undertaken more profitable investment opportunities, which influence performance positively. Thus, when management is forced to repay more debt, the free cash flow may be reduced, as suggested by Jensen and Meckling (1976), which would alleviate agency costs.

Foundation ownership is widespread in Denmark and there has been much discussion for and against foundation ownership, as it seems to violate the classical principal agent model. A foundation does not have any owners and the board is self selective. Very often the proceeds are denoted to charities, so at first sight, foundation ownership seems to conflict with the neoclassical assumption about the profit maximizing firm. Thus, foundation ownership may hamper market liquidity, since the shares held by 
the foundation very often are not traded at all. Therefore, institutional investors would be less interested in buying shares in firms with substantial foundation ownership.

This is also the case for firms relying on shares with dual class voting rights. The reason is that very often a foundation holds the shares with the superior voting rights, whereas the normal shares are traded at the stock exchange. This has also been recognized by the large st Danish institutional investors, which have publicly expressed their critique against the use of shares with dual class voting rights, which are very common in Denmark. In addition, recent studies show that foundation ownership, as well as the presence of takeover defenses do not impact firm performance, see Thomsen and Rose (2004) and Rose (2002). This article makes use of 3SLS taking into account the correlation between the residuals in the equations (all calculations are done in SAS)

\section{Results}

Table 1 shows descriptive statistics of the sample. Notice that the aggregate average ownership in a firm by institutional investors is 19 percent.

\section{[INSERT TABLE 1]}

Compared to other industrialized countries, ownership by Danish institutional investors seems to be relatively low. Banks and insurance companies own a low proportion of equity of Danish listed firms and this is especially true for mutual funds (investeringsforeninger), which only account for less than one percent in a firm.

Pension funds own on average just above three percent, which in an international perspective seems as a moderate ownership stake, although the maximum ownership percent is high, more precisely 81 percent. The dominance by the two largest institutional shareholders is striking, since they account for more than ten percent on average and are by far the two most important players. 
A plausible reason, why Danish institutional investors are less dominant owners than their foreign colleagues might be that the Danish welfare system provides social benefits, when people retire from the work force or leave the workforce for other reasons. This may hamper people's incentives to invest, e.g. in pension funds. However, there are other legal impediments that restrict the ownership by Danish institutional investors, especially for banks and for insurance companies.

\section{[INSERT TABLE 2]}

Table 2 depicts the correlation matrix of the variables (a few variables have been omitted due to space limitations). It is interesting to notice that there is a high negative significant correlation between Tobin's q and aggregate ownership by institutional investors as well as mutual funds, pension funds and ATPLD. Notice also that foreign ownership, which may include foreign institutional investors and aggregate ownership by Danish institutional investors, is significantly negatively correlated. Thus, firm size is high positively correlated with the ownership by ATP and LD. There is also a negative significant correlation between ownership by those two institutions and foreign ownership.

The result of the regression analysis using 3SLS is displayed in table 3 where both Tobin's q and the aggregate ownership by Danish institutional investors serve as endogenous variables. In the following, only results of the first structural equation are displayed.

\section{[INSERT TABLE 3]}

Table 3 reveals that aggregate ownership by Danish institutional investors influences firm performance negatively, although not significantly. The control variable OPTIONS is positive and significantly different from zero. Firm size also significantly impacts firm performance, although negatively, which is also the case for the shipping industry dummy (measured against the 
manufacturing industry), although only on a 10 percent level. None of the year dummies are significant (measured against 1998). Using non linear 3SLS, where the variable INST is squared (the coefficient is still negative), as well as raised to the second power (positive coefficient), does not change the results either, i.e. aggregate ownership by institutional investors does not impact firm performance significantly. There is reason to believe that it matters, if an institutional investor increases his holding from 9-10 percent, compared to an increase from 8-9 percent. The reason is that when ownership passes certain thresholds, a shareholder obtains certain specific minority rights granted by the Danish Company Act. For instance, when a shareholder owns at least 10 percent, he may call for an extraordinary general meeting, demand a minority auditor or an investigation of the firms financial status, etc. Pursuant to Danish law, changing the company's articles of incorporation needs the approval by two thirds of the votes and the represented capital at the general meeting. As a consequence, a shareholder holding 34 percent may block such amendments, and thereby resist any fundamental change in the company's status. This analysis follows the approach formulated by Himmelberg, Hubbard and Palia (1999) uncovering, if the effect is influenced by the current ownership level (piece wise regression).

Table 4 reveals that there is a significant negative effect on performance when aggregate institutional shareholding is increased in the range from zero to 10 percent. However, this picture is not maintained in the ownership intervals of 10-33 percent as well as above 33 percent (not shown in the article)

\section{[INSERT TABLE 4]}

Table 5 reveals an interesting relation, namely that ownership by the two largest institutional investors in Denmark, i.e. LD and ATP, impacts firm performance negatively. Both control variables, LNSIZE, 
and OPTIONS, are also significantly different from zero. This is also the case when the variable LDATP is squared hypothesising a concave relationship between firm performance and ownership. The coefficient is negative and significantly different from zero (the results in the latter situation are not shown in the article).

\section{[INSERT TABLE 5]}

Table 6 shows that ownership by pension funds does not influence firm performance. The dummy variable in year 2001 is significant, which is also the case for the variables SIZE and SHIP. Notice, however that the estimated equation does not explain much of the variation in the data, since one cannot reject that all the coefficients are zero. Therefore, the evidence suggests that ownership by pension funds does not influence firm performance.

\section{[INSERT TABLE 6]}

Table 7 shows the effect on firm performance from an increase in the ownership by mutual funds (investeringsforeninger). The coefficient is negative and significant on a ten percent level. The following control variables are all significantly different from zero: OPTIONS, SHIP, SIZE, YEAR2000 and YEAR2001. The Variable INVEST is also significant, when taking the squared root of INVETS (not shown in the article).

\section{[INSERT TABLE 7]}

The next table shows how ownership by banks influences firm performance. Table 8 reveals that contrary to the previous results, banks have a positive significant impact on firm performance. The 
coefficient is 0,115 and the significance level is below five percent. The following control variables are also significantly different from zero: OPTIONS, SHIP and to a lesser extent also TRADE. This is repeated, when some of the control variables are excluded from the equation, since BANK remains significantly different from zero and positive. This is also the case when the variable BANK is squared, c.f. the lower part of table 8 .

\section{[INSERT TABLE 8]}

The effect of ownership by insurance companies on firm performance is depicted in table 9. The variable INSUR is positive and significantly different from zero on a ten percent level. The following control variables are also significant: OPTIONS, SHIP and SIZE. The results are insignificant when taking the square root of INSUR. Notice, however that the estimated equation only accounts for a relatively low degree of the variation of firm performance, although this is not unusual in crosssectional models of firm performance. Ownership by foreigners does not influence firm performance. Running four separate regressions does not change the results. This is also the case when I estimate the regression but use an indicator variable for each firm since firm year observations may not be independent.

[INSERT TABLE 9] 


\section{Discussion}

As shown, the formulated hypothesis must be rejected, as one cannot content that institutional investors may discipline managers in order to run the firm more in the interests of shareholders and thereby maximizing profit. There might be several reasons why aggregate ownership by Danish institutional investors does not impact performance. First, one cannot take it for certain that institutional investors are effective enough to coordinate their actions that are necessary to put real pressure on the incumbent management. Even though, there are no legal constraints, such as in the US, for large shareholders to coordinate their actions against management, institutional investors might disagree on how management should be challenged. At the same time, it is an open question if the institutional investors have necessary power to challenge management, as they often hold the shares with the inferior voting rights (the $\mathrm{B}$ shares).

LD and ATP were both founded by law more than a decade ago. LD was formed because in the seventies the government decided not to compensate employees' wages for the increase of inflation. Instead, the government declared that the amount should be laid in the hand of a fund that would invest the money, and later on people would be compensated. ATP was also founded by the government in order to increase the pension payments made by all Danish employees. The results support the view that enhancing the ownership by the two largest institutional owners does not influence firm performance positively. On the other hand, it seems implausible to suspect that these two investors deprive private benefits at the expense of the minority shareholders or to allege that LD and ATP diminish firm value. Moreover, the results seem to indicate that their pressure was not sufficient to change corporate policy in a direction that could strengthen the process of value, creation i.e. shareholder value. In recent years, both ATP and LD have been very active in exercising their ownership, adopting several of the principles formulated in the Danish code of good corporate 
governance, i.e. the Nørby report. Therefore, it seems as an obvious task for future research in this area to uncover, if the negative relation, which is found in this analysis, at present still prevails.

As mentioned, legal impediments may hamper the activism of institutional investors. To illustrate, the Act that governs ATP and LD contains in paragraph 6(3) a statement requiring both funds not to own equities in a given firm, if they become dominant owners, e.g. when they are in a position to elect all the members on the supervisory board etc.

Banks and insurance companies are also restricted, since Danish law puts some restrictions on their ability to own non-financial firms. The Act (Lov om Finansiel Virksomhed) states in paragraph 24 that banks and insurance companies can be allowed by the authorities to operate firms, which businesses are accessory to these firms. However, they are allowed to own equity in any firm, as long that they do not have a dominant ownership position (paragraph 26). Legal restrictions may, therefore, be a serious constraint in the ability of institutional investors to exercise active ownership.

The results show that increased ownership by banks and insurance companies increase firm performance. Due to the legal impediments faced by banks and insurance companies, they are not allowed to be active owners hence a possible explanation for the results may be that both types of firms are able to make superior investments in listed firms (recall that the ownership held by banks and insurance companies is relatively small). Specifically, it might be the case that portfolio managers employed by banks are subjected to a more competitive performance pressure from top bank officers.

One of the policy implications of the articles finding is that more attention should be devoted to mitigate the principalagent problem within the organization of institutional investors. More precisely, one should pay attention to how an institutional investor's supervisory board provides incentives to portfolio managers, so that they benefit from their active ownership on behalf of the fund.

Recall, that agency theory states that if a manager is supposed to carry out two different tasks, the marginal benefit to the agent must be equal, otherwise he/she will simply neglect the task with the 
lowest marginal benefit. Portfolio managers hired by institutional investors should therefore be rewarded financially, if they participate in active ownership, e.g. representing the funds equity holdings at the general meeting and when being active in monitoring and controlling management. Moreover, institutional investors should not be treated as a homogenous group of investors, but should be analysed separately, focusing on each institutional investor's ability to engage in active ownership, and how this is accomplished at the lowest costs. This might involve a more formal coordination procedure when exercising their ownership stakes between institutional investors, which might include a specialization among the institutional investors.

\section{Conclusion}

Ownership by institutional investors has become especially widespread in recent years, hence institutional investors have become the capitalists of our time. Thus, this urges the question of whether this development benefits investors in the first place. In particular, shareholders who are constraint from exercising their property rights due to the free rider problem associated with dispersed ownership.

This article tests the hypothesis that increased ownership by institutional investors' impact firm performance positively. The hypothesis must be rejected, but decomposing the results reveals that ownership by banks and to a lesser extent insurance companies has a positive significant impact on firm performance measured by Tobin's q. The largest two institutional investors in Denmark, ATP and LD, have a negative significant impact on firm performance during the period of the sample covering the years; 1998-2001. It is suggested that more attention should be paid to the design of incentive contracts within institutional investors in order to mitigate the agency problems. 
It is an open question whether the results of the article can be generalized to other European countries or are robust over a long-term period of time. Moreover, the article tries to uncover the black box view of institutional investors showing that different institutional investors may impact managerial incentives differently, and as a consequence, it contributes to the debate on the role of institutional investors.

Table 1. Descriptive statistics

\begin{tabular}{|l|l|r|r|r|r|r|}
\hline Variable & Label & Maximum & Mean & Minimum & $\mathbf{N}$ & Std Dev \\
\hline \hline Q & Q & 4.8889538 & 1.1708957 & 0.3326603 & 434 & 0.6799575 \\
INST & INST & 89.8600000 & 19.0706682 & 0 & 434 & 17.4727417 \\
INSUR & INSUR & 33.8700000 & 2.2590323 & 0 & 434 & 5.0813831 \\
BANK & BANK & 42.0100000 & 2.3472055 & 0 & 433 & 5.7414053 \\
INVEST & INVEST & 25.0400000 & 0.8860829 & 0 & 434 & 3.3763273 \\
PENS & PENS & 80.9500000 & 3.2468664 & 0 & 434 & 9.0242465 \\
LDATP & LDATP & 34.4700000 & 10.3368894 & 0 & 434 & 9.3218008 \\
FOREIGN & FOREIGN & 100.0000000 & 4.9218433 & 0 & 434 & 13.4851739 \\
OPTIONS & OPTIONS & 1.0000000 & 0.3686636 & 0 & 434 & 0.4829993 \\
LNCAPEXP & LNCAPEXP & 8.1297644 & 2.7919239 & -2.8824036 & 434 & 1.9222855 \\
LNSIZE & LNSIZE & 10.8505790 & 6.7885836 & 0 & 434 & 1.8009310 \\
DUALCL & DUALCL & 1.0000000 & 0.4585253 & 0 & 434 & 0.4988519 \\
TRUST & TRUST & 79.1000000 & 5.9954608 & 0 & 434 & 13.5202054 \\
\hline
\end{tabular}


Table 2. Correlation Matrix

\begin{tabular}{|c|c|c|c|c|c|c|c|c|c|}
\hline \multicolumn{10}{|c|}{$\begin{array}{l}\text { Pearson Correlation Coefficients } \\
\text { Prob > |r| under H0: Rho }=0 \\
\text { Number of Observations }\end{array}$} \\
\hline & $\mathrm{Q}$ & INST & INSUR & BANK & INVEST & PENS & LDATP & FOREIGN & LNSIZE \\
\hline $\begin{array}{l}\mathrm{Q} \\
\mathrm{Q}\end{array}$ & $\begin{array}{l}1.00000 \\
443\end{array}$ & & & & & & & & \\
\hline $\begin{array}{l}\text { INST } \\
\text { INST }\end{array}$ & $\begin{array}{l}-0.15102 \\
0.0014 \\
443\end{array}$ & $\begin{array}{l}1.00000 \\
443\end{array}$ & & & & & & & \\
\hline $\begin{array}{l}\text { INSUR } \\
\text { INSUR }\end{array}$ & $\begin{array}{l}-0.05143 \\
0.2801 \\
443\end{array}$ & $\begin{array}{l}0.46913 \\
<.0001 \\
443\end{array}$ & $\begin{array}{l}1.00000 \\
443\end{array}$ & & & & & & \\
\hline $\begin{array}{l}\text { BANK } \\
\text { BANK }\end{array}$ & $\begin{array}{l}-0.02746 \\
0.5647 \\
442\end{array}$ & $\begin{array}{l}0.54599 \\
<.0001 \\
442\end{array}$ & $\begin{array}{l}0.27861 \\
<.0001 \\
442\end{array}$ & $\begin{array}{l}1.00000 \\
442\end{array}$ & & & & & \\
\hline $\begin{array}{l}\text { INVEST } \\
\text { INVEST }\end{array}$ & $\begin{array}{l}-0.08087 \\
0.0891 \\
443\end{array}$ & $\begin{array}{l}0.32000 \\
<.0001 \\
443\end{array}$ & $\begin{array}{l}0.11006 \\
0.0205 \\
443\end{array}$ & $\begin{array}{l}-0.03351 \\
0.4822 \\
442\end{array}$ & $\begin{array}{l}1.00000 \\
443\end{array}$ & & & & \\
\hline $\begin{array}{l}\text { PENS } \\
\text { PENS }\end{array}$ & $\begin{array}{l}-0.11421 \\
0.0162 \\
443\end{array}$ & $\begin{array}{l}0.49973 \\
<.0001 \\
443\end{array}$ & $\begin{array}{l}-0.03366 \\
0.4798 \\
443\end{array}$ & $\begin{array}{l}0.00928 \\
0.8457 \\
442\end{array}$ & $\begin{array}{l}0.02435 \\
0.6093 \\
443\end{array}$ & $\begin{array}{l}1.00000 \\
443\end{array}$ & & & \\
\hline $\begin{array}{l}\text { LDATP } \\
\text { LDATP }\end{array}$ & $\begin{array}{l}-0.09918 \\
0.0369 \\
443\end{array}$ & $\begin{array}{l}0.68729 \\
<.0001 \\
443\end{array}$ & $\begin{array}{l}0.15678 \\
0.0009 \\
443\end{array}$ & $\begin{array}{l}0.26181 \\
<.0001 \\
442\end{array}$ & $\begin{array}{l}0.17651 \\
0.0002 \\
443\end{array}$ & $\begin{array}{l}-0.02280 \\
0.6322 \\
443\end{array}$ & $\begin{array}{l}1.00000 \\
443\end{array}$ & & \\
\hline $\begin{array}{l}\text { FOREIGN } \\
\text { FOREIGN }\end{array}$ & $\begin{array}{l}-0.03018 \\
0.5263 \\
443\end{array}$ & $\begin{array}{l}-0.14695 \\
0.0019 \\
443\end{array}$ & $\begin{array}{l}-0.06569 \\
0.1675 \\
443\end{array}$ & $\begin{array}{l}-0.06159 \\
0.1962 \\
442\end{array}$ & $\begin{array}{l}-0.03016 \\
0.5266 \\
443\end{array}$ & $\begin{array}{l}-0.06790 \\
0.1537 \\
443\end{array}$ & $\begin{array}{l}-0.12582 \\
0.0080 \\
443\end{array}$ & $\begin{array}{l}1.00000 \\
443\end{array}$ & \\
\hline $\begin{array}{l}\text { LNSIZE } \\
\text { LNSIZE }\end{array}$ & $\begin{array}{l}-0.02991 \\
0.5301 \\
443\end{array}$ & $\begin{array}{l}0.07097 \\
0.1358 \\
443\end{array}$ & $\begin{array}{l}0.00876 \\
0.8542 \\
443\end{array}$ & $\begin{array}{l}0.00004 \\
0.9994 \\
442\end{array}$ & $\begin{array}{l}-0.05758 \\
0.2265 \\
443\end{array}$ & $\begin{array}{l}-0.10965 \\
0.0210 \\
443\end{array}$ & $\begin{array}{l}0.25466 \\
<.0001 \\
443\end{array}$ & $\begin{array}{l}0.07444 \\
0.1177 \\
443\end{array}$ & $\begin{array}{l}1.00000 \\
443\end{array}$ \\
\hline
\end{tabular}


Table 3. 3SLS of Tobin's q with instruments: OPTIONS and LNCAPEXP. Instruments for INST are DUALCL and TRUST. Adjusted $\mathrm{R}^{2}$ is equal to 5,6 percent and the $\mathrm{F}$ value is 3,86 .

\begin{tabular}{|l|l|l|l|l|l|l|}
\hline \multicolumn{2}{|l|}{ Parameter Estimates } & \multicolumn{2}{l|}{} & \\
\hline Variable & $\begin{array}{l}\text { D } \\
\text { F }\end{array}$ & $\begin{array}{l}\text { Parameter } \\
\text { Estimate }\end{array}$ & Standard Error & t Value & Pr $>|t|$ & $\begin{array}{l}\text { Variable } \\
\text { Label }\end{array}$ \\
\hline Intercept & 1 & 1.715184 & 0.244935 & 7.00 & $<.0001$ & Intercept \\
\hline INST & 1 & -0.00722 & 0.010334 & -0.70 & 0.4852 & INST \\
\hline OPTIONS & 1 & 0.291349 & 0.075146 & 3.88 & 0.0001 & OPTIONS \\
\hline LNCAPEXP & 1 & 0.012047 & 0.031770 & 0.38 & 0.7047 & LNCAPEXP \\
\hline TRADE & 1 & -0.05344 & 0.072380 & -0.74 & 0.4607 & TRADE \\
\hline SHIP & 1 & -0.28904 & 0.168435 & -1.72 & 0.0869 & SHIP \\
\hline LNSIZE & 1 & -0.07637 & 0.032099 & -2.38 & 0.0178 & LNSIZE \\
\hline YEAR1999 & 1 & -0.01376 & 0.087851 & -0.16 & 0.8756 & YEAR1999 \\
\hline YEAR2000 & 1 & 0.044428 & 0.087891 & 0.51 & 0.6135 & YEAR2000 \\
\hline YEAR2001 & 1 & -0.03077 & 0.089000 & -0.35 & 0.7297 & YEAR2001 \\
\hline
\end{tabular}


Table 4. 3SLS of Tobin's q with instruments: OPTIONS and LNCAPEXP. Instruments for INST010 are DUALCL and TRUST. Adjusted $\mathrm{R}^{2}$ is equal to 5,8 percent and the $\mathrm{F}$ value is 3,99 .

\begin{tabular}{|l|l|l|l|l|l|l|}
\hline \multicolumn{2}{|l|}{ Parameter Estimates } & \multicolumn{2}{l|}{} & \\
\hline Variable & $\begin{array}{l}\text { D } \\
\text { F }\end{array}$ & $\begin{array}{l}\text { Parameter } \\
\text { Estimate }\end{array}$ & Standard Error & t Value & Pr $>|t|$ & $\begin{array}{l}\text { Variable } \\
\text { Label }\end{array}$ \\
\hline Intercept & 1 & 2.055828 & 0.257634 & 7.98 & $<.0001$ & Intercept \\
\hline INST0-10 & 1 & -0.07232 & 0.037842 & -1.91 & 0.0567 & INST1 \\
\hline OPTIONS & 1 & 0.220744 & 0.073974 & 2.98 & 0.0030 & OPTIONS \\
\hline LNCAPEXP & 1 & -0.00931 & 0.033936 & -0.27 & 0.7840 & LNCAPEXP \\
\hline TRADE & 1 & -0.09261 & 0.077788 & -1.19 & 0.2345 & TRADE \\
\hline SHIP & 1 & -0.31926 & 0.182288 & -1.75 & 0.0806 & SHIP \\
\hline LNSIZE & 1 & -0.05831 & 0.026088 & -2.24 & 0.0259 & LNSIZE \\
\hline YEAR1999 & 1 & 0.012165 & 0.070929 & 0.17 & 0.8639 & YEAR1999 \\
\hline YEAR2000 & 1 & 0.089225 & 0.070957 & 1.26 & 0.2093 & YEAR2000 \\
\hline YEAR2001 & 1 & 0.026956 & 0.071838 & 0.38 & 0.7077 & YEAR2001 \\
\hline
\end{tabular}


Table 5. 3SLS of Tobin's q with instruments: OPTIONS and LNCAPEXP. Instruments for LDATP are DUALCL and TRUST. Adjusted $\mathrm{R}^{2}$ is equal to 5,7 percent and the $\mathrm{F}$ value is 9,84 .

\begin{tabular}{|l|l|l|l|l|l|l|}
\hline Parameter Estimates & \multicolumn{2}{l|}{} & \multicolumn{2}{l|}{} \\
\hline Variable & $\begin{array}{l}\mathrm{D} \\
\mathrm{F}\end{array}$ & $\begin{array}{l}\text { Parameter } \\
\text { Estimate }\end{array}$ & Standard Error & $\mathrm{t}$ Value & Pr $>|\mathrm{t}|$ & $\begin{array}{l}\text { Variable } \\
\text { Label }\end{array}$ \\
\hline Intercept & 1 & 2.119361 & 0.172593 & 12.28 & $<.0001$ & Intercept \\
\hline LDATP & 1 & -0.03338 & 0.014494 & -2.30 & 0.0218 & LDATP \\
\hline OPTIONS & 1 & 0.230819 & 0.079010 & 2.92 & 0.0037 & OPTIONS \\
\hline LNCAPEXP & 1 & 0.034776 & 0.032204 & 1.08 & 0.2808 & LNCAPEXP \\
\hline TRADE & 1 & 0.097959 & 0.065111 & 1.50 & 0.1332 & TRADE \\
\hline SHIP & 1 & -0.18573 & 0.150508 & -1.23 & 0.2179 & SHIP \\
\hline LNSIZE & 1 & -0.12019 & 0.028636 & -4.20 & $<.0001$ & LNSIZE \\
\hline YEAR1999 & 1 & -0.00976 & 0.077520 & -0.13 & 0.8999 & YEAR1999 \\
\hline YEAR2000 & 1 & 0.079638 & 0.077607 & 1.03 & 0.3054 & YEAR2000 \\
\hline YEAR2001 & 1 & 0.001119 & 0.078588 & 0.01 & 0.9887 & YEAR2001 \\
\hline
\end{tabular}

\begin{tabular}{|c|c|c|c|c|c|c|}
\hline \multicolumn{7}{|c|}{ Parameter Estimates } \\
\hline Variable & $\begin{array}{l}\mathrm{D} \\
\mathrm{F}\end{array}$ & $\begin{array}{l}\text { Parameter } \\
\text { Estimate }\end{array}$ & Standard Error & t Value & $\operatorname{Pr}>|t|$ & $\begin{array}{l}\text { Variable } \\
\text { Label }\end{array}$ \\
\hline Intercept & 1 & 1.914964 & 0.117441 & 16.31 & $<.0001$ & Intercept \\
\hline LDATP & 1 & -0.02781 & 0.012016 & -2.31 & 0.0211 & LDATP \\
\hline OPTIONS & 1 & 0.259923 & 0.069028 & 3.77 & 0.0002 & OPTIONS \\
\hline LNSIZE & 1 & -0.08138 & 0.021044 & -3.87 & 0.0001 & LNSIZE \\
\hline
\end{tabular}


Table 6. 3SLS of Tobin's q with instruments: OPTIONS and LNCAPEXP. Instruments for PENS are DUALCL and TRUST. Adjusted $\mathrm{R}^{2}$ is close to zero percent and the F value is 0,85 .

\begin{tabular}{|l|l|l|l|l|l|l|}
\hline \multicolumn{2}{|l|}{ Parameter Estimates } & \multicolumn{2}{l|}{} & \\
\hline Variable & $\begin{array}{l}\mathrm{D} \\
\mathrm{F}\end{array}$ & $\begin{array}{l}\text { Parameter } \\
\text { Estimate }\end{array}$ & Standard Error & $\mathrm{t}$ Value & Pr $>|\mathrm{t}|$ & $\begin{array}{l}\text { Variable } \\
\text { Label }\end{array}$ \\
\hline Intercept & 1 & 1.745639 & 0.683554 & 2.55 & 0.0110 & Intercept \\
\hline PENS & 1 & 0.106078 & 0.124761 & 0.85 & 0.3957 & PENS \\
\hline OPTIONS & 1 & 0.428354 & 0.228982 & 1.87 & 0.0621 & OPTIONS \\
\hline LNCAPEXP & 1 & 0.024051 & 0.073727 & 0.33 & 0.7444 & LNCAPEXP \\
\hline TRADE & 1 & 0.248130 & 0.109800 & 2.26 & 0.0243 & TRADE \\
\hline SHIP & 1 & -0.62173 & 0.251554 & -2.47 & 0.0138 & SHIP \\
\hline LNSIZE & 1 & -0.14315 & 0.047960 & -2.98 & 0.0030 & LNSIZE \\
\hline YEAR1999 & 1 & -0.19914 & 0.128961 & -1.54 & 0.1233 & YEAR1999 \\
\hline YEAR2000 & 1 & -0.22385 & 0.129059 & -1.73 & 0.0836 & YEAR2000 \\
\hline YEAR2001 & 1 & -0.38960 & 0.130701 & -2.98 & 0.0030 & YEAR2001 \\
\hline
\end{tabular}


Table 7. 3SLS of Tobin's q with instruments: OPTIONS and LNCAPEXP. Instruments for INVEST are DUALCL and TRUST. Adjusted $\mathrm{R}^{2}$ is equal to 5,0 percent and the F value is 3,51.

\begin{tabular}{|l|l|l|l|l|l|l|}
\hline \multicolumn{2}{|l|}{ Parameter Estimates } & \multicolumn{2}{l|}{} & \\
\hline Variable & $\begin{array}{l}\mathrm{D} \\
\mathrm{F}\end{array}$ & $\begin{array}{l}\text { Parameter } \\
\text { Estimate }\end{array}$ & Standard Error & $\mathrm{t}$ Value & Pr $>|\mathrm{t}|$ & $\begin{array}{l}\text { Variable } \\
\text { Label }\end{array}$ \\
\hline Intercept & 1 & 1.625242 & 0.151924 & 10.70 & $<.0001$ & Intercept \\
\hline INVEST & 1 & -0.09855 & 0.056466 & -1.75 & 0.0817 & INVEST \\
\hline OPTIONS & 1 & 0.337069 & 0.089411 & 3.77 & 0.0002 & OPTIONS \\
\hline LNCAPEXP & 1 & 0.002971 & 0.026984 & 0.11 & 0.9124 & LNCAPEXP \\
\hline TRADE & 1 & 0.047154 & 0.061729 & 0.76 & 0.4454 & TRADE \\
\hline SHIP & 1 & -0.50980 & 0.142810 & -3.57 & 0.0004 & SHIP \\
\hline LNSIZE & 1 & -0.05218 & 0.027181 & -1.92 & 0.0556 & LNSIZE \\
\hline YEAR1999 & 1 & -0.09245 & 0.073713 & -1.25 & 0.2105 & YEAR1999 \\
\hline YEAR2000 & 1 & -0.17025 & 0.073784 & -2.31 & 0.0215 & YEAR2000 \\
\hline YEAR2001 & 1 & -0.25828 & 0.074716 & -3.46 & 0.0006 & YEAR2001 \\
\hline
\end{tabular}


Table 8. 3SLS of Tobin's q with instruments: OPTIONS and LNCAPEXP. Instruments for BANK are DUALCL and TRUST. Adjusted $\mathrm{R}^{2}$ is equal to 2,1 percent and the $\mathrm{F}$ value is 2,23. Below is displayed the results when the variable is squared.

\begin{tabular}{|l|l|l|l|l|l|l|}
\hline \multicolumn{2}{|l|}{ Parameter Estimates } & \multicolumn{2}{l|}{} & \\
\hline Variable & $\begin{array}{l}\text { D } \\
\text { F }\end{array}$ & $\begin{array}{l}\text { Parameter } \\
\text { Estimate }\end{array}$ & Standard Error & t Value & Pr $>|t|$ & $\begin{array}{l}\text { Variable } \\
\text { Label }\end{array}$ \\
\hline Intercept & 1 & 1.038503 & 0.191678 & 5.42 & $<.0001$ & Intercept \\
\hline BANK & 1 & 0.115454 & 0.047109 & 2.45 & 0.0147 & BANK \\
\hline OPTIONS & 1 & 0.226373 & 0.104687 & 2.16 & 0.0312 & OPTIONS \\
\hline LNCAPEXP & 1 & -0.01863 & 0.029001 & -0.64 & 0.5210 & LNCAPEXP \\
\hline TRADE & 1 & -0.10762 & 0.064163 & -1.68 & 0.0942 & TRADE \\
\hline SHIP & 1 & -0.64109 & 0.146448 & -4.38 & $<.0001$ & SHIP \\
\hline LNSIZE & 1 & -0.01101 & 0.027948 & -0.39 & 0.6938 & LNSIZE \\
\hline YEAR1999 & 1 & -0.00366 & 0.075168 & -0.05 & 0.9612 & YEAR1999 \\
\hline YEAR2000 & 1 & -0.06881 & 0.075215 & -0.91 & 0.3608 & YEAR2000 \\
\hline YEAR2001 & 1 & -0.07810 & 0.076243 & -1.02 & 0.3062 & YEAR2001 \\
\hline
\end{tabular}

\begin{tabular}{|l|l|l|l|l|l|l|}
\hline \multicolumn{2}{|l|}{ Parameter Estimates } & \multicolumn{2}{l|}{} \\
\hline Variable & $\begin{array}{l}\text { D } \\
\text { F }\end{array}$ & $\begin{array}{l}\text { Parameter } \\
\text { Estimate }\end{array}$ & Standard Error & t Value & Pr $>|t|$ & $\begin{array}{l}\text { Variable } \\
\text { Label }\end{array}$ \\
\hline Intercept & 1 & 0.998010 & 0.102609 & 9.73 & $<.0001$ & Intercept \\
\hline SQBANK & 1 & 0.269332 & 0.141476 & 1.90 & 0.0576 & SQBANK \\
\hline OPTIONS & 1 & 0.292622 & 0.083769 & 3.49 & 0.0005 & OPTIONS \\
\hline LNCAPEXP & 1 & -0.04270 & 0.017920 & -2.38 & 0.0176 & LNCAPEXP \\
\hline
\end{tabular}


Table 9. 3SLS of Tobin's q with instruments: OPTIONS and LNCAPEXP. Instruments for INSUR are DUALCL and TRUST. Adjusted $\mathrm{R}^{2}$ is equal to 1,2 percent and the $\mathrm{F}$ value is 2,81 .

\begin{tabular}{|l|l|l|l|l|l|l|}
\hline Parameter Estimates & \multicolumn{2}{|l|}{} & \\
\hline Variable & $\begin{array}{l}\text { D } \\
\text { F }\end{array}$ & $\begin{array}{l}\text { Parameter } \\
\text { Estimate }\end{array}$ & Standard Error & t Value & Pr $>|t|$ & $\begin{array}{l}\text { Variable } \\
\text { Label }\end{array}$ \\
\hline Intercept & 1 & 1.466977 & 0.230029 & 6.38 & $<.0001$ & Intercept \\
\hline INSUR & 1 & 0.090040 & 0.055890 & 1.61 & 0.1079 & INSUR \\
\hline OPTIONS & 1 & 0.352639 & 0.092450 & 3.81 & 0.0002 & OPTIONS \\
\hline LNCAPEXP & 1 & 0.011358 & 0.040503 & 0.28 & 0.7793 & LNCAPEXP \\
\hline TRADE & 1 & -0.12051 & 0.089672 & -1.34 & 0.1797 & TRADE \\
\hline SHIP & 1 & -0.44384 & 0.205774 & -2.16 & 0.0316 & SHIP \\
\hline LNSIZE & 1 & -0.07994 & 0.039329 & -2.03 & 0.0427 & LNSIZE \\
\hline YEAR1999 & 1 & -0.06002 & 0.106440 & -0.56 & 0.5731 & YEAR1999 \\
\hline YEAR2000 & 1 & -0.04506 & 0.106444 & -0.42 & 0.6723 & YEAR2000 \\
\hline YEAR2001 & 1 & -0.16515 & 0.107807 & -1.53 & 0.1263 & YEAR2001 \\
\hline
\end{tabular}

\begin{tabular}{|c|c|c|c|c|c|c|}
\hline \multicolumn{7}{|c|}{ Parameter Estimates } \\
\hline Variable & $\begin{array}{l}\mathrm{D} \\
\mathrm{F}\end{array}$ & $\begin{array}{l}\text { Parameter } \\
\text { Estimate }\end{array}$ & Standard Error & t Value & $\operatorname{Pr}>|t|$ & $\begin{array}{l}\text { Variable } \\
\text { Label }\end{array}$ \\
\hline Intercept & 1 & 1.367220 & 0.148829 & 9.19 & $<.0001$ & Intercept \\
\hline INSUR & 1 & 0.084727 & 0.049322 & 1.72 & 0.0865 & INSUR \\
\hline OPTIONS & 1 & 0.333589 & 0.079041 & 4.22 & $<.0001$ & OPTIONS \\
\hline SHIP & 1 & -0.44635 & 0.168479 & -2.65 & 0.0084 & SHIP \\
\hline LNSIZE & 1 & -0.07220 & 0.021475 & -3.36 & 0.0008 & LNSIZE \\
\hline
\end{tabular}




\section{References}

Ackert, L. F. and G. Athanassakos (2001) "Visibility, institutional Preferences and agency considerations", Journal of Psychology and Financial Markets", 2, 201-209

Admati, A.R, P. Pfleiderer and J. Zechner (1994) "Large shareholder activism, risk sharing and financial markets equilibrium”, Journal of Political Economy, 102, 1097-1130

Blair, M. (1995) "Ownership and Control. Rethinking corporate governance for the twenty first century”, The Bookings Institution, Washington D.C.

Bhagat, S, B. Black and M. Blair (2004) "Relational investing and firm performance" , Journal of Financial Research 27, 1-30

Burkart, M., D. Gromb and F. Panunzi (1997) "Large shareholders, monitoring and the value of the firm”, Quarterly Journal of Economics, August, 693-728

Coffee, J, Jr. (1991) "Liquidity versus control: The institutional investor as corporate monitor", Columbia Law Review 91, 6

Conrad, J., K.M. Johnson and S. Wahal (2002) “The Trading of Institutional Investors and Firm Characteristics, Journal of Applied Finance, 12, (1) 
Davis, E. P (2002) “Institutional investors, corporate governance and the performance of the corporate sector”, Economic Systems 26, 202-229

Duggal, R and J. A. Millar (1999) "Institutional ownership and firm performance: The case of bidder returns", Journal of Corporate Finance 5, 103-117

Fama, E. (1983) "Agency problems and residual claims", Journal of Law and Economics, 26, 327-349

Franks, J. and C. Mayer (1990) “Capital markets and corporate control”, Economic Policy, April

Gompers, P. A. and A. Metrick (2001) “Institutional Investors and Equity Prices”, Quarterly Journal of Economics, February, 229-259

Hartzell, J. C. and L. T. Starks (2003) "Institutional investors and executive compensation", Journal of Finance, 58, 2351-2374

Himmelberg, Charles P., R. Glenn Hubbard and Darius Palia (1999) "Understanding the determinants of managerial ownership and the link between ownership and performance", Journal of Financial Economics, 53, pp.353-384

La Porta, R., L de-Silanes, A. Schleifer and R.W. Vishny (1997) "Legal determinants of external finance", Journal of Finance, 52, 1131-1150

Monks, R. A.G and N. Minow (2002) "Corporate Governance” 2.ed. Blackwell Business 
Neumann, R. and T. Neumann (2003) "Does ownership matter in the presence of strict antiactivism legislation? Evidence from equity transactions in Denmark", International Review of Financial Analysits 12, 157-171

Kahn, C. and A. Winton (1998) “Ownership Structure, Speculation, and shareholder intervention”, Journal of Finance 53, 99-129

Louderer, K. C. and K. Martin (1997) "Executive stock ownership and performance. Tracking faint trees", Journal of Financial Economics 45, 112-144

Louis, K., C. Chan and J. Lokonishok (1993) "Institutional trades and intraday stock price behavior", Journal of Financial Economics, 33, 173-199

Prevost, A. K. and R. P. Roa (2000) "Of what value are shareholder proposals sponsored by public pension funds?" Journal of Business, 73, 177-204

Roe, M. (199 ) "Some differences in Corporate structure in Germany, Japan and the United States", Yale Law Review, 102, 1927-1999

Rose, C. (2002) “Takeover defenses impact on corporate financial performance”, European Journal of Law and Economics, 13, 91-112

Rose, C. (2002) "Stakeholder orientation vs. shareholder value. A matter of contractual failures", European Journal of Law and Economics, 18, 77-97 
Romano, R. (1993) "Public pension fund activism in corporate governance revisited, Columbia Law Review 93, 794-853

Shleifer, A. and R. W. Vishny (1997) “A survey of corporate governance”, Journal of Finance, 52, $737-783$

Sias, R. W. and L. T. Starks (1997) "Return autocorrelation and institutional investors", Journal of Financial Economics, 46, 103-130

Thomsen, S. and C. Rose (2004) "Do companies need owners? Foundation ownership and firm performance", forthcoming in the European Journal of Law and Economics.

Van den Berge, L. (2002) “Corporate Governance in a globalising world: Convergence or Divergence?" Kluwer Academic Publishers.

Wahal, S. and J. J. McConell (2000) "Do institutional investors exacerbate managerial myopia?" Journal of Corporate Finance 6, 307-329 